Volume 1, Number 1, 2015

\title{
Heat Stability in Exterior Walls in the Summer
}

\author{
Vasyl Zhelyh, Stepan Shapoval*, Mykola Hensetskyy, Iryna Venhryn \\ Lviv Polytechnic National University, 12, Bandera Str., Lviv, 79013, Ukraine
}

Received: April 10, 2015. Revised: May 14, 2015. Accepted: June 15, 2015.

(c) 2015 The Authors. Published by Lviv Polytechnic National University.

\begin{abstract}
One of the main parameters that determine room climate is the internal temperature therein, which depends on projected external construction of the building. So, first of all, the article analyzes the heat resistance of the external construction of the building which is derived from thermal protection of the building, especially in the summer. Thermal effect on the external construction of the building has been analyzed primarily from the point of impact of solar radiation on the construction in the summer. Parameters that affect the thermal resistance of the external construction of the building during the summer season have been investigated, namely the relationship between the solar radiation absorption coefficient by the material of the external construction of the building and dependence of the temperature fluctuations amplitude on the external construction of the building has been examined. The influence of airflow in July, as an important parameter that affects the heat transfer coefficient of the outer surface of the external construction of the building for summer conditions has been analyzed.
\end{abstract}

Keywords: solar radiation; external construction of the building; heat transfer coefficient; the amplitude of temperature fluctuations; amount of heat.

\section{Introduction}

At the present stage of Ukraine development, the necessary task is to reduce energy costs because energy efficiency of alternative fuels in Ukraine is a priority.

Progressive changes in society and nature are not possible without constant energy use. No human activity can be carried out without the use of various forms of energy, which is why it is important to analyze heat loss and gain in the room.

\section{Definition of the scientific problem}

Compliance with the requirements for the buildings us based on the principle of alternative design of the external construction of the building. An important parameter that determines the microclimate of the premises is the room temperature which depends on the projected external construction of the building, external conditions and the presence of heat and gas supply in the building.

However, the room temperature under the influence of solar radiation on the external construction of the building can be increased, and its value will not match the comfortable conditions of the room, especially this could happen in the summer.

\section{Analysis of key publications and research}

The intensity of the solar energy reaching the Earth's surface is variable in nature during the day, month, year. Based on meteorological data[1], it has been determined that the average total density of solar energy in January in Ukraine is descending from south to north, changing within $90-60 \mathrm{~W} / \mathrm{m}^{2}$, while the summer is characterized by small changes in solar radiation (change within 313-316 W/m²) [2].

Analysis of the impact of solar radiation on the amplitude of fluctuations in the external construction of the building is bsed on determining the attenuation of the estimated fluctuations amplitude of conventional (total) ambient temperature in the external construction of the building [3].

${ }^{*}$ Corresponding author. E-mail address: shapovalstepan@qmail.com 


\section{The aim of the article}

The aim of this research was to analyze basic dependencies that affect the heat protection of the room in the summer season, including analysis of parameters that influence the amplitude of fluctuations in temperature on the inner surface of the external construction of the building and the amount of heat that the outer surface gives to the inner air in the premises.

\section{Presentation and discussion of the research results}

To determine the maximum amount of heat that gives the inner external construction surface gives to the room, the following equation is applied (1):

$$
q_{\max }=\alpha_{B} \cdot A \tau_{B}, \mathrm{~W} / \mathrm{m}^{2}
$$

where $\alpha \mathrm{B}$ - heat transfer coefficient of the inner surface of the external construction, $\mathrm{W} /\left(\mathrm{m} 2 \cdot{ }^{\circ} \mathrm{C}\right) ; \mathrm{A} \tau_{\mathrm{B}}-$ the amplitude of the inner external construction surface fluctuations, ${ }^{\circ} \mathrm{C}$.

The value of the amplitude of fluctuations in temperature on the inner surfaceof the external construction is determined by the equation (2):

$$
A \tau_{\text {B }}=\frac{A t_{3}^{\mathrm{calc}}}{v}
$$

where $A t_{3}^{\text {calc }}$ - the calculated amplitude fluctuations of conventional (total) ambient temperature, that is the amplitude of daily fluctuations in ambient temperature with regard to solar radiation; $v$ - the value of the calculated outside air temperature amplitude attenuation $A t_{3}^{\text {calc }},{ }^{\circ} \mathrm{C}$.

The heat transfer coefficient of the outer surface of the ecternal construction for summer conditions is defined by the equation (3) [4]

$$
\alpha_{3}^{\prime}=1.16 \cdot \sqrt{v}, \mathrm{~W} /\left(\mathrm{m}^{2} \cdot{ }^{\circ} \mathrm{C}\right)
$$

where $v$ - the lowest of the average wind speeds for the points of the compass in July the frequency of which is $16 \%$ or more, but not less than $1 \mathrm{~m} / \mathrm{sec}$.

The shell of the building consisting of homogeneous layers successively placed is accepted:

- $\quad$ lime-sand plaster $\delta=0.015 \mathrm{~m}, \lambda=0.93 \mathrm{~W} /\left(\mathrm{m}^{\circ}{ }^{\circ} \mathrm{C}\right)$;

- $\quad$ brick $\delta=0.38 \mathrm{~m}, \lambda=0.64 \mathrm{~W} /\left(\mathrm{m} \cdot{ }^{\circ} \mathrm{C}\right)$;

- $\quad$ polystyrene plates $\delta=0.115 \mathrm{~m}, \lambda=0.055 \mathrm{~W} /\left(\mathrm{m} \cdot{ }^{\circ} \mathrm{C}\right)$;

- $\quad$ cement-sand plaster $\delta=0.015 \mathrm{~m}, \lambda=0.81 \mathrm{~W} /\left(\mathrm{m} \cdot{ }^{\circ} \mathrm{C}\right)$.

Given the change in the lowest average wind speeds for the points of the compass in July, it is advisable to analyze the dependence of the heat transfer coefficient of the outer surface of the external construction on the airflow for summer conditions $\dot{\alpha}_{3}, \mathrm{~W} /\left(\mathrm{m}^{2} \cdot{ }^{\circ} \mathrm{C}\right)$.

The results of analytical studies are presented in Fig. 1.

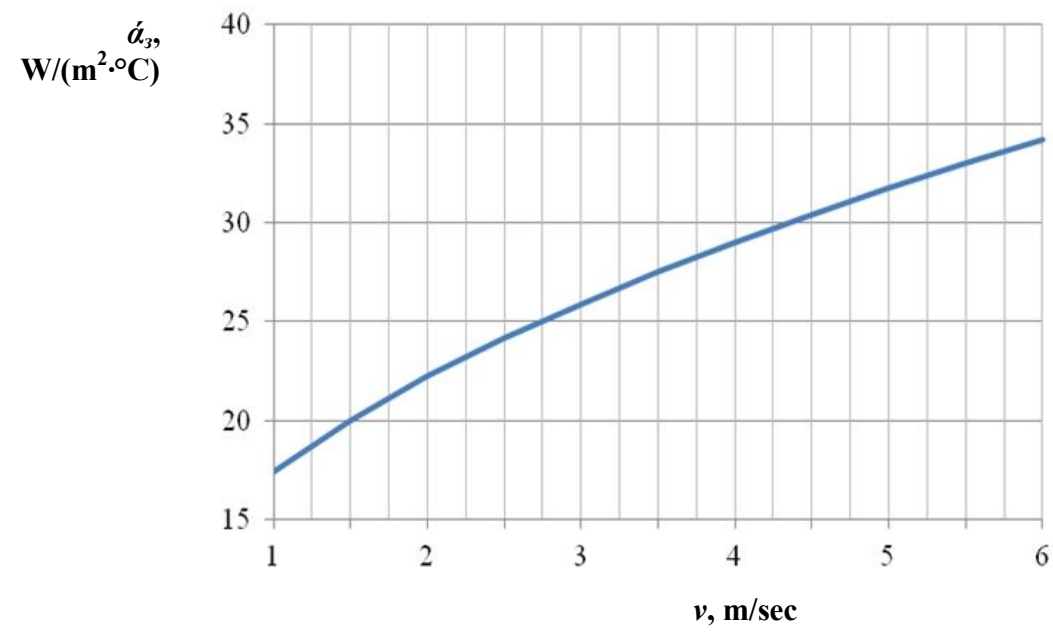

Fig. 1. Dependence of the outer surface heat transfer $\dot{\alpha}_{3}$ on the speed of air flow $v$ 
From additional literature, we found out that the absorption coefficient of solar radiation by material of the outer surface $\rho$ varies for construction materials from 0.3 to 0.9 [5].

Intervals of factors variation are presented in Table 1.

Table 1. Levels of factors and varying intervals

\begin{tabular}{|c|c|c|c|c|}
\hline \multirow{2}{*}{ Factor } & \multirow{2}{*}{ Code } & \multicolumn{2}{|c|}{ Levels of factors } & \multirow{2}{*}{$\Delta x_{i}$} \\
\cline { 3 - 4 } & & -1 & +1 & \\
\hline \hline$\rho$ & $x_{1}$ & 0.3 & 0.9 & 0.3 \\
\hline$A_{\text {rad }}$ & $x_{2}$ & 50 & 850 & 400 \\
\hline
\end{tabular}

Results of analytical calculations of dependancies of the amplitude of fluctuations in temperature on the inner surface of the esternal construction $A \tau_{6}$ on the amplitude of solar radiation $A_{\text {rad }}$ and the absorption coefficient of solar radiation by the material of the external construction $\rho$ are presented in Table 2 .

Table 2. Results of analytical calculations

\begin{tabular}{|c|c|c|}
\hline$\rho$ & $A_{\text {rad }}$ & $A \tau_{b}$ \\
\hline \hline 0.3 & 100 & 0.13 \\
\hline 0.3 & 500 & 0.19 \\
\hline 0.3 & 900 & 0.24 \\
\hline 0.9 & 100 & 0.16 \\
\hline 0.9 & 500 & 0.33 \\
\hline 0.9 & 900 & 0.50 \\
\hline
\end{tabular}

Based on the data from Table 2 graphic dependancies of the amplitude of oscillation of the inner surface of the external construction on the amplitude of fluctuations of the solar radiation and the absorption coefficient of solar radiation by the material of the external construction have been built.

Fig. 2. The dependence of the oscillation amplitude of the temperature on the inner surface $A \tau_{b}$ on the amplitude of the solar radiation $A_{\text {rad }}$ and the coefficient of absorption of solar radiation by the external construction material $\rho$

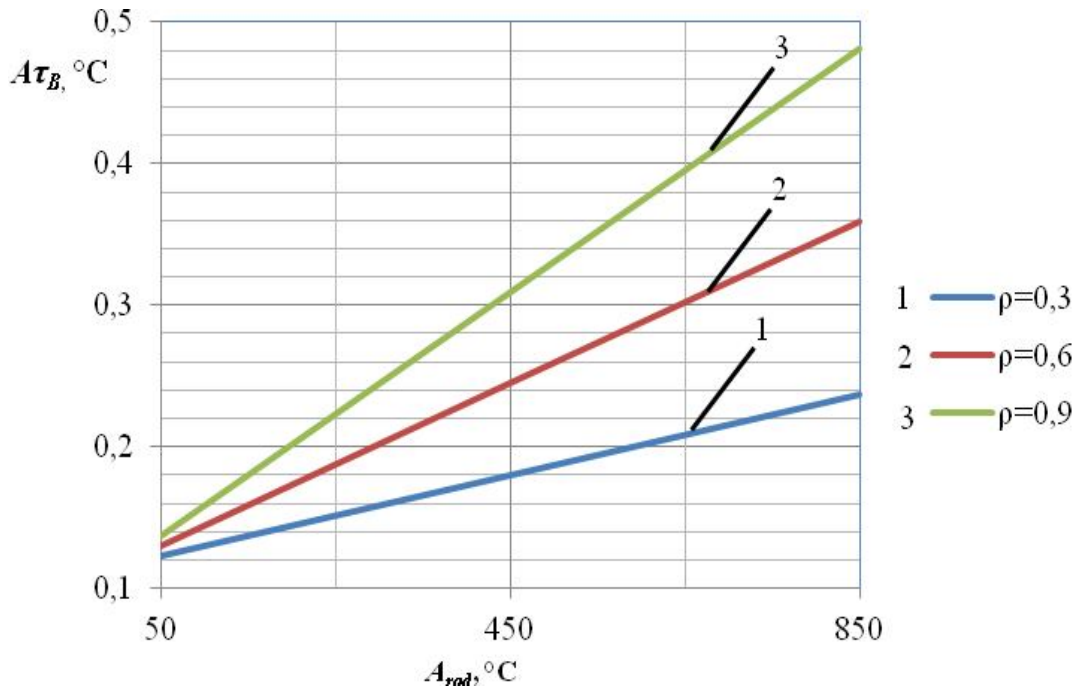


Based on Fig. 2, we have received formula of dependancy of the amplitude of temperature fluctuations on the inner surface $A \tau_{6}$ on the coefficient of absorption of solar radiation by the external construction material $\rho$ and amplitude fluctuations of solar radiation $A_{\text {rad }}(4)$ :

$$
A \tau_{b}=0.1151+0.0014 \cdot \rho-\frac{3.9583}{10^{7}} \cdot A_{\text {rad }}-0.0013 \cdot \rho^{2}+0.0005 \cdot \rho \cdot A_{\text {rad }}+\frac{2.0833}{10^{10}} \cdot A_{\text {rad }}{ }^{2},{ }^{\circ} \mathrm{C}
$$

where $A \tau_{6}$ - amplitude of temperature fluctuations of the inner surface of the external construction, ${ }^{\circ} \mathrm{C} ; \rho-$ absorption coefficient of solar radiation by the external construction material; $A_{\text {rad }}$ - amplitude of solar radiation fluctuations, ${ }^{\circ} \mathrm{C}$.

\title{
6. Conclusions
}

A result of analysis of the impact of thermal resistance parameters of the external construction during the summer, it wasfound that the rate of absorption of solar radiation by the external construction material has significant impact on the amplitude of the oscillations of the inner surface of the external construction with the simultaneous growth of $A_{\text {rad }}$. Including changes in $\rho$ from 0.3 to 0.6 causes the changes in $A \tau_{b}$ by 0.025 with the amplitude of solar radiation fluctuations $A_{\text {rad }}=50{ }^{\circ} \mathrm{C}$, but with the increase in $A_{\text {rad }}$ from 50 to $850{ }^{\circ} \mathrm{C} A \tau_{b}$ will change by 0.2 . So absorbing property of the surface of the external construction for solar radiation will affect the calculated temperature of the outdoor air and the maximum amount of heat transferred to the internal air through the external construction for higher values $A_{\text {rad }}$.

\section{References}

[1] Building Climatology. DSTU - H B V. 1.1 - 27: 2010. - Kyiv : MRDC, 2011 - 123 p. (in Ukrainian)

[2] Shapoval C. P. "Prospects of solar energy in Ukraine" / C. P. Shapoval, I. I. Venhryn // Young Scientist. - 2014. - № 7. - 21-24 p. (in Ukrainian)

[3] Bogoslovskyy V. N. / "Construction thermophysics" / V. N. Bogoslovsky // Textbook for high schools. $-2^{\text {nd }}$ ed., rev. and add. - Moscow : Higher. School, 1982. - 415 p. (in Russian)

[4] Ratushniak G. S. Design for the protection of buildings thermophysical parameters : manual / G. S. Ratushniak, G. S. Popova. - Vinnytsya : VDTU, 2003. - 78 p. (in Ukrainian)

[5] The thermal insulation of buildings. DBN V.2.6-31: 2006. - № 1 with the change of July 1, 2013. - Kyiv : MRDC, 2006 - 70 p. (in Ukrainian)

[6] Mysak J. S. Solar power: Theory and Practice: monograph / J. S. Mysak, O. T. Voznyak, A. S. Dacko, S. P. Shapoval. - Lviv : Lviv Polytechnic National University Publishing House, 2014. - 340 p. (in Ukrainian)

[7] Malyarenko V. Energy efficiency / V. Malyarenko, L. Lisak. - Kharkiv : Rubicon, 2004. - 360 p. (in Ukrainian)

[8] Matveev Y. Current statistical review / Y. Matveev // Zelena enerhetyka. - 2003. - № 3. - 4-6 p. (in Ukrainian)

\section{Теплостійкість зовнішнього огородження у літній період року}

\author{
Василь Желих, Степан Шаповал, Микола Генсецький, Ірина Венгрин \\ Національний університет “Львівська політехніка”, вул. С. Бандери 12, м. Львів, 79013, Україна
}

\section{Анотація}

Одним із основних параметрів, що визначає мікроклімат приміщення, є внутрішня температура у ньому, яка залежать від запроектованого зовнішнього захищення. Тому насамперед у статті проаналізовано теплостійкість захищення, яка $\epsilon$ похідною від теплозахисту будівлі, зокрема в літній період. Теплове надходження на зовнішне огородження проаналізовано переважно 3 точки впливу сонячної радіації на конструкцію в літній час. Досліджено параметри, які впливають на теплостійкість захищення в літній період року, а саме: розглянуто взаємозв'язок коефіцієнта поглинання сонячної радіації матеріалом зовнішнього захищення й залежності амплітуди коливання температури на внутрішній поверхні захищення. Проаналізовано вплив швидкості повітряного потоку в липні як важливого параметра, що впливає на коефіцієнт тепловіддачі зовнішньої поверхні захищення для літніх умов.

Ключові слова: сонячна радіація; зовнішнє захищення; коефіцієнт тепловіддачі; амплітуда коливання температури; кількість теплоти. 